\title{
STIMULASI PERKEMBANGAN SPIRITUALITAS LANSIA DI KELURAHAN PARAK GADANG TIMUR KOTA PADANG
}

\author{
Windy Freska*), Dewi Eka Putri dan Tiara Yalita \\ Program Studi Profesi Ners Fakultas Keperawatan Universitas Andalas \\ *) Email: windyfreska88@nrs.unand.ac.id
}

\begin{abstract}
ABSTRAK
Saat ini populasi lansia di Indonesia sebesar 9,27\%. Lansia mengalami beberapa penurunan di berbagai aspek perkembangan seperti biologis, kognitif, psikologis, sosial, dan spiritual. Penurunan perkembangan pada lansia akan menurunkan kesejahteraan mental lansia. Hal itu juga disebabkan kurangnya pemberian stimulasi perkembangan pada lansia sehingga diperlukannya pemenuhan kebutuhan spiritual sebagai suatu stimulasi perkembangan untuk meningkatkan kesejahteraan kesehatan mental lansia. Tujuan kegiatan adalah untuk mengetahui pengaruh pendidikan kesehatan stimulasi perkembangan spiritualitas pada lansia di RW VIII Kelurahan Parak Gadang Timur. Intervensi pendidikan kesehatan stimulasi perkembangan spiritualitas dilaksanakan dengan memberikan pengetahuan aspek spiritual dan ceramah kepada responden. Desain Quasi eksperimen sebelum dan sesudah tanpa grup kontrol. Perolehan data dilakukan menggunakan kuisioner pengetahuan aspek spiritual lansia untuk memberikan pengetahuan aspek spiritual pada lansia dan Spirituality Orientation Inventery (SOI) untuk menilai gambaran spiritualitas lansia dengan menggunakan uji paired sample $\mathrm{t}$ test. Dari hasil kegiatan didapatkan skor pengetahuan lansia yaitu rata-rata sebelum 0,72 poin dan sesudah 2,27 poin, dan didapatkan peningkatan pengetahuan sebelum dan sesudah sebesar 1,56 poin dan menunjukkan adanya pengaruh yang bermakna pada pengetahuan lansia sebelum dan sesudah intervensi $(\mathrm{p}<0,05)$. Gambaran tingkat spiritual lansia didapatkan nilai median $=53$ dengan kategori $\geq 53$ baik. Diharapkan kepada petugas pelayanan kesehatan untuk melakukan kegiatan spiritual yang terjadwal untuk memenuhi kebutuhan spiritual pada lansia untuk menjaga kesehatan pada lansia.
\end{abstract}

Kata Kunci: lansia, stimulasi, perkembangan

\section{Stimulation of The Development of Lansian Spirituality in Parak Gadang Timur Village, Padang City}

\begin{abstract}
Currently, the elderly population in Indonesia is $9.27 \%$. The elderly experience some decline in development, such as biological, cognitive, psychological, social, and spiritual. The decline in development in the elderly will reduce the mental well-being of the elderly. This is also due to the lack of developmental stimulation in the elderly so that spiritual needs are needed as a developmental stimulation to improve the mental health welfare of the elderly. The purpose of the activity was to determine the effect of stimulating health education on the development of spirituality in the elderly in RW VIII, Parak Gadang Timur Village. Health education interventions to stimulate the development of spirituality are carried out by providing knowledge of spiritual aspects and lectures to respondents. Quasi-experimental design before and after without a control group. Data were collected using a questionnaire on the spiritual factors of the elderly to provide knowledge on the elderly's spiritual aspects and a Spirituality Orientation Inventory (SOI) to assess the elderly's spirituality using the paired sample t-test. From the results of the activity, it was obtained that the knowledge score of the elderly was an average before 0.72 points and after 2.27 points, and an increase in knowledge before and after was 1.56 points and showed a significant influence on the knowledge of the elderly before and after the intervention ( $\mathrm{p} .<0.05)$. The description of the spiritual level of the elderly obtained the median value = 53 with the category $\geq 53$ good. It is hoped that health care workers carry out scheduled spiritual activities to fulfill the spiritual needs of the elderly to maintain their health.
\end{abstract}

Keywords: elderly, stimulation, development 


\section{PENDAHULUAN}

Kesehatan Jiwa menurut Undang undang Nomor 18 Tahun 2014 merupakan suatu kondisi dimana seorang individu dapat berkembang secara fisik, mental, spiritual dan sosial sehingga individu tersebut menyadari kemampuan sendiri, dapat mengatasi tekanan, dapat bekerja secara produktif dan mampu memberikan kontribusi untuk komunitasnya. Saat ini, terdapat peningkatan yang nyata pada populasi lansia di seluruh dunia, yang tercermin dalam peningkatan populasi lansia, yang dianggap sebagai lansia dalam kaitannya dengan usia kronologis 60 tahun atau lebih (Inegi, 2014) karena pertambahan kelompok lansia ini terus meningkat yang menjadi pembahasan jika tahun-tahun kehidupan dijalani dengan kualitas kesehatan yang baik, jadi sangat penting bahwa penuaan divisualisasikan dari perspektif perhatian dan perawatan yang mendukung menjalaninya sepenuhnya (Mendoza, 2018).

Cara hidup menua dan tua berbeda-beda, hal ini bergantung pada karakteristik sosial budaya dimana lansia berkembang, terkadang ditandai dengan kemunduran. Bagaimanapun, usia tua harus dijalani dengan kepenuhan, kepuasan hidup dan dengan rasa kualitas hidup yang optimal. Perkembangan lansia adalah menyesuaikan terhadap perubahan fisik, psikologis, sosial ekonomi, menjaga kepuasan hidup, dan mencari cara untuk mempertahankan kualitas hidup. Guna mencapai kualitas hidup lansia diperlukan kemampuan lansia dalam beradaptasi terhadap kondisi fisik, psikologis, tingkat kemandirian dan hubungan dengan lingkungan (Reno, 2010). Mengingat hal tersebut lansia membutuhkan dukungan untuk menyesuaikan dengan perkembangan dalam hidupnya untuk mencapai integritas diri yang utuh.

Tercapainya integritas diri yang utuh adalah perkembangan psiko-sosial yang normal pada lansia. Pemahaman terhadap makna hidup secara keseluruhan membuat lansia berusaha menuntun generasi berikutnya (anak dan cucunya). Pentingnya kesehatan jiwa pada lansia karena apabila lansia tidak mencapai integritas diri maka lansia akan merasa putus asa dan menyesali masa lalunya karena tidak merasakan hidupnya bermakna. Lansia yang mampu menyesuaikan diri terhadap keberhasilan dan kegagalan dalam hidupnya akan mencapai perkembangan integritas, sebaliknya lansia yang gagal akan mengalami despair yaitu memandang kehidupan dengan lebih negatif, sehingga mereka memandang hidup mereka secara keseluruhan dengan ragu-ragu, suram, putus asa (Varcarolis dan Halter, 2010). Hal ini juga dapat disebabkan oleh kurangnya pemberian stimulasi perkembangan pada lansia. Stimulasi perkembangan pada lansia merupakan suatu tindakan untuk meningkatkan aspek-aspek perkembangan yang normal pada lansia.

Terdapat 5 aspek perubahan alamiah atau normal yang terjadi pada proses menua, yaitu aspek biologis, aspek psikologis, aspek sosial, aspek seksualitas dan aspek spiritual. Salah satu aspek pada lansia yaitu aspek spiritual. Aspek dalam spiritual antara lain: harapan, kedamaian, cinta, kasih, sayang, bersyukur dan keyakinan. Sebagai individu yang telah mencapai usia lanjut, lansia normal memerlukan keyakinan lebih untuk menghadapi perubahan-perubahan pada dirinya, yaitu kebutuhan spiritual. Kebutuhan spiritual merupakan salah satu kebutuhan dasar manusia untuk mencari tujuan dan harapan hidup (Hamid, 2000). Seperti yang dijelaskan pada penelitian Ibrahim (2013) bahwa didapat karakteristik spiritual pada lanjut usia berada pada kategori baik yaitu sebanyak 33 orang (61\%), hubungan dengan Tuhan berada pada 
kategori baik yaitu sebanyak 30 orang (56\%), hubungan dengan diri sendiri berada pada kategori baik yaitu sebanyak 38 orang (70\%), hubungan dengan orang lain berada pada kategori kurang yaitu sebanyak 32 orang (59\%), dan hubungan dengan alam berada pada kategori baik yaitu sebanyak 34 orang $(63 \%)$.

Spiritualitas adalah segala aspek yang berkaitan dengan hubungan seseorang dengan kehidupan non materi atau kekuatan yang lebih tinggi. Spiritualitas merupakan konsep dua dimensi yaitu dimensi vertikal dan horizontal. (Stanley, 2012) 9Spiritualitas dapat membantu seseorang untuk diyakinkan akan apa yang terjadi, itu adalah bagian dari kekuatan yang lebih tinggi. (Tuhan). Menurut penelitian, keyakinan spiritual sangat penting karena dapat memengaruhi tingkat kesehatan dan perilaku perawatan diri klien . Berdasarkan hasil penelitian menunjukkan semakin baik spiritualitas lansia akan memotivasi mereka untuk menjaga kesehatan. Hasil penelitian menunjukkan adanya hubungan yang signifikan antara spiritualitas lansia dengan gaya hidup.1 Artinya, spiritualitas yang baik akan membuat gaya hidup sehat. dan tentunya akan meningkatkan derajat kesehatan lansia.

Pemenuhan kebutuhan spiritual juga penting untuk meningkatkan kesejahteraan lansia dan dapat mengisi kelengkapan perkembangan lansia. Menurut penelitian yang dilakukan oleh Ibrahim (2013), disebutkan bahwa lansia yang tergabung dalam kelompok atau komunitas terutama dalam kegiatan spiritual atau keagamaan memiliki tingkat kesejahteraan yang baik. Hal ini menunjukkan bahwa perlunya pemenuhan tugas perkembangan salah satunya adalah pemenuhan kebutuhan spiritual lansia secara kelompok atau komunitas di suatu wilayah untuk meningkatkan kesejahteraan lansia.

Salah satu terapi non farmakologis yang baik digunakan untuk lansia adalah terapi religius (bimbingan rohani, doa dan zikir dan keyakinan) (Ibrahim, 2013). Berdasarkan hasil studi pendahuluan di Kelurahan Parak Gadang Timur, didapatkan data jumlah penduduk adalah 9.281 jiwa. jumlah lanjut usia adalah 648 jiwa sementara untuk RW VIII terdapat 45 orang lansia Selain hasil tersebut, dilakukan wawancara kepada ketua RW 08 bahwa penduduk yang dominan di daerah RW 08 adalah usia anak sekolah dan lanjut usia. Hasil wawancara juga dilakukan kepada 10 orang lansia bahwa di RW 08 masih minim dilakukan kegiatan keagamaan terkait pemenuhan spiritual lansia.

Selain itu, wawancara juga dilakukan kepada kader kesehatan yang ada di RW 08, didapatkan bahwa dahulu ada kegiatan keagamaan yaitu majelis taklim namun kegiatan tersebut sudah tidak terjalani lagi dikarenakan adanya masalah pemindahan jabatan. Oleh karena itu kader kesehatan mengatakan perlu untuk diadakannya kegiatan keagamaan di wilayah RW 08. Berdasarkan hasil pengkajian awal dari pihak puskesmas didapatkan data bahwa puskesmas belum ada kerja sama pihak puskesmas maupun kelurahan dengan pihak lain untuk mengatasi pemenuhan kebutuhan spiritual pada lansia di RW 08.

Berdasarkan penjelasan tersebut, penulis tertarik untuk melakukan penelitian tentang Pengaruh Pendidikan Kesehatan Stimulasi Perkembangan Spiritualitas Lansia di Wilayah RW 08 Parak Gadang Timur Padang. 


\section{METODOLOGI}

Desain penelitian quasi eksperimen dengan jenis penelitian sebelum dan sesudah tanpa grup kontrol. Intervensi dilakukan dengan menggunakan alat ukur berupa kuisioner yaitu kuisioner tentang pengetahuan stimulasi perkembangan aspek spiritual dan kuisioner Spirituality Orientation Inventery (SOI) untuk mengukur gambaran spiritualitas lansia. Hasil pengetahuan pada lansia diuji menggunakan uji paired sample t test.

Kegiatan terapi spiritual pada lansia dilakukan pada tanggal 22 November 2019 di RW VIII Parak Gadang Timur dengan responden 18 orang lansia dengan kegiatan berupa pemberian pengetahuan aspek spiritual pada lansia dan ceramah sebagai pemenuhan kebutuhan spiritual lansia oleh ustadz dari Dompet Dhuafa.

\section{HASIL DAN PEMBAHASAN}

Kegiatan ini dilaksanakan dengan tujuan untuk mengetahui pengaruh pendidikan kesehatan stimulasi perkembangan spiritualitas pada lansia di RW VIII Kelurahan Parak Gadang Timur. Intervensi pendidikan kesehatan stimulasi perkembangan spiritualitas dilaksanakan dengan memberikan pengetahuan aspek spiritual dan ceramah kepada responden. Berikut Distribusi Frekuensi Lansi berdasarkan Karakteristik.

Tabel 1. Distribusi Frekuensi Lansia Berdasarkan Karakteristik di RW VIII Parak Gadang Timur 2019 $(\mathrm{n}=18)$

Berdasarkan tabel diatas yang menjelaskan karakteristik lansia dalam pemberian intervensi pendidikan kesehatan stimulasi perkembangan spiritualitas lansia di RW VIII Parak Gadang Timur yaitu sebagian besar berjenis kelamin perempuan $(89 \%)$ dengan usia lebih dari setengah $(72 \%)$ berusia $>75$ tahun.

diberikan

Setelah

intervensi

pendidikan

kesehatan

stimulasi

perkembangan

aspek spiritual

Karakteristik Responden n Jenis Kelamin

Laki-laki

Perempuan

Usia

$<75$ tahun

$>75$ tahun

pada lansia

didapatkan hasil yaitu untuk pengetahuan lansia menunjukkan adanya peningkatan pengetahuan sebelum dan sesudah intervensi sebesar 1.56 point. Hasil uji paired sample $t$ test menunjukkan adanya pengaruh yang bermakna pada pengetahuan aspek spiritual lansia sebelum dan sesudah diberi intervensi $(p<0,05)$ yang menunjukkan bahwa terdapat peningkatan yang signifikan terhadap pengetahuan aspek spiritual pada lansia. Sesuai dengan yang ditampilkan pada 
Hasil Intervensi yang dilakukan untuk memenuhi kebutuhan spiritual lansia yaitu memberikan stimulasi perkembangan berupa pendidikan kesehatan tentang kebutuhan spiritual pada lansia dan melakukan terapi religius. Salah satu terapi non farmakologis yang baik digunakan untuk lansia adalah terapi religious (bimbingan rohani, doa dan zikir dan keyakinan).

Tabel 2. Rata-rata Skor Pengetahuan Aspek Spiritual Lansia Sebelum dan Sesudah dilakukan Pendidikan Kesehatan tentang Aspek Spiritual Lansia di RW VIII Parak Gadang Timur Tahun $2019(\mathrm{n}=18)$

\begin{tabular}{l|c|c|c}
\hline Pengetahuan & Mean & Standar Deviasi & P value \\
\hline Sebelum & 0.72 & 1.31 & 0,001 \\
Sesudah & 2.28 & 1.56 & 0,001 \\
\hline
\end{tabular}

Gambaran spiritualitas lansia setelah diberikan kuisioner sebelum dilakukan intervensi didapatkan hasil median $=53$ point dengan kategori $\geq 53$ point memiliki tingkat spiritual yang baik. Gambaran spiritualitas yang dimiliki lansia yaitu lebih dari setengah $(67 \%)$ lansia memiliki tingkat spiritual yang baik seperti yang ditampilkan pada gambar

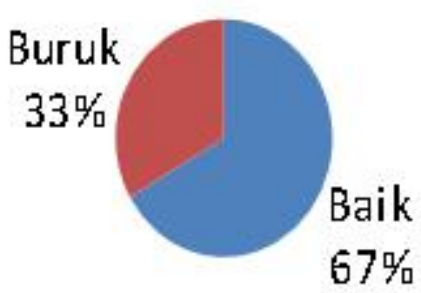

Gambar 1. Gambaran Tingkat Spiritualitas Lansia di RW VIII Parak Gadang Timur Tahun 2019

Hasil yang didapatkan setelah diberikan intervensi berupa stimulasi spiritualitas pada lansia yaitu didapatkan gambaran spiritualitas lansia sebesar $67 \%$ baik dengan sebagian besar responden lansia berjenis kelamin perempuan dan berusia $\geq 75$ tahun yang menunjukkan bahwa lansia di RW VIII Parak Gadang Timur telah memiliki pemenuhan kebutuhan spiritual yang baik dan hal itu didukung oleh penjelasan Stanley (2012) bahwa semakin lanjut usia seseorang maka akan semakin tinggi kesadaran akan kebutuhan spiritualnya.

Hasil pemberian intervensi pendidikan kesehatan stimulasi perkembangan berupa pengetahuan aspek spiritual yaitu terjadi peningkatan pada pengetahuan lansia tentang aspek spiritual lansia. Hal ini menunjukkan bahwa pemberian stimulasi berupa pendidikan kesehatan aspek spiritual pada lansia berhasil meningkatkan pengetahuan yang dimiliki lansia tentang aspek spiritual pada lansia. Sejalan dengan penelitian Suliswati (2014) bahwa pendidikan kesehatan yang dilakukan pada masyarakat 
ditujukan untuk meningkatkan derajat kesehatan jiwa yang optimal bagi masyarakat, sehingga masyarakat mampu mengatasi masalahnya dan meningkatkan pengetahuannya.

Spiritualitas menjadi sangat penting untuk kesehatan fisik pada lansia (Taylor, 2013). Pada saat yang sama, hal itu dapat berdampak signifikan pada kualitas hidup Lansia. Organisasi Kesehatan Dunia (WHO) menggambarkan kualitas hidup sebagai konsep kompleks yang mencakup keyakinan fisik, psikologis dan sosial dan berpendapat bahwa ada enam domain luas yang mengidentifikasi aspek inti kualitas hidup. Salah satu domain tersebut adalah keyakinan / spiritualitas pribadi (makna dalam hidup). Lebih lanjut mereka menegaskan bahwa domain kesehatan dan kualitas hidup saling melengkapi dan tumpang tindih. Ini dengan jelas menyiratkan bahwa WHO melihat korelasi yang berbeda antara spiritualitas dan kesehatan umum. Penelitian selanjutnya yang menggunakan instrumen uji lapangan WHOQoL juga telah menunjukkan pentingnya hubungan ini (Rusa et al., 2015; Skevington, Gunson, \& O’Connell, 2013). Dalam proyek Badan Kualitas Perawatan Lansia Australia (2015) ditemukan selama percakapan dengan peserta bahwa, "Kesejahteraan psikologis dan spiritual serta inklusi sosial secara teratur dikutip sebagai faktor kunci dalam perawatan berkualitas.

Hal ini juga sejalan dengan penelitian Ibrahim (2010) yang menjelaskan bahwa sebanyak 56\% lansia memiliki pemenuhan kebutuhan spiritual yang baik setelah diberikan terapi spiritual. Terapi religius yang diberikan dengan memberikan ceramah, doa dan zikir serta peningkatan keyakinan merupakan suatu stimulus dalam upaya untuk meningkatkan motivasi dalam pelaksanaan kegiatan keagamaan untuk memenuhi kebutuhan spiritual dan merupakan salah satu upaya tercapainya integritas diri yang utuh pada lansia Pendekatan terapi non farmakologi kini sering digunakan dalam peningkatan kesehatan baik fisik maupun mental pada lansia dan terapi religius merupakan pilihan terapi yang tepat diberikan pada lansia. (Videbeck, 2008).

\section{KESIMPULAN DAN SARAN}

Dari kegiatan yang dilakukan di RW VIII Kelurahan Parak Gadang Timur hasilnya cukup baik dan dapat diterima. Dari kegiatan dengan intervensi pendidikan kesehatan stimulasi perkembangan spiritual hasilnya sudah cukup baik dengan menunjukkan adanya peningkatan pengetahuan lansia yang signifikan tentang aspek spiritual lansia.

Kegiatan ini dapat dilakukan secara rutin oleh petugas kesehatan setempat dengan sasaran Lansia di masyarakat yang membutuhkan pelayanan kesehatan dengan meningkatkan kesehatan dengan pendekatan spiritualitas.

\section{DAFTAR PUSTAKA}

Dinata, WW. 2015. Menurunkan Tekanan Darah Pada Lansia Melalui Senam Yoga. JOP, Yogyakarta. 
Guslinda, Keliat dan Widyastuti. 2001. Pengaruh terapi kelompok Terapeutik Lansia Terhadap Kemampuan Adaptasi dan Perkembangan Integritas Diri Lansia di Kelurahan Surau Gadang Kecamatan Nanggalo Padang. Thesis. Universitas Indonesia

Harminarti N, Hasmiwati N, Adrial. 2019. Peran serta kader dalam pendeteksian dan pencegahan infekdi cacing usus di kelurahan Korong Gadang Kecamatan Kuranji Padang. Jurnal Hilirisasi IPTEKS. Vol 2 No 4.a (2019): Desember 2019DOI: https://doi.org/10.25077/jhi.v2i4.a.305http://hilirisasi.lppm.unand.ac. id/index.php/hilirisasi/article/view/305/112

Ibrahim, HS., Suriani, Ira. 2010. Hubungan Terapi Religius Dengan Stress Psikososial Pada Lanjut Usia. INJ, Banda Aceh.

Ibrahim. 2013. Karakteristik Spiritual Pada Lanjut Usia di Unit Pelaksana Teknis Dinas (UPTD) Rumah Sejahtera Geunaseh Sayang Banda Aceh Tahun 2013. Banda Idea Nursing Journal, Aceh.

Instituto Nacional de Estadística y Geografía (INEGI). Perfil sociodemográfico de adultos mayores [Internet]. Mexico: INEGI; 2014 [cited 2018 Dec 01]. Availablefrom: http://internet.contenidos.inegi.org.mx/contenidos/productos/pr od_serv/contenidos/espanol/bvinegi/productos/censos/poblacion/2010/perfil_s ocio/adultos/702825056643.pdf [ Links ]

Kartinah., Sudaryanto, Agus. 2008. Masalah Psikososial Pada Lanjut Usia. FIKUMS, Kartasura.

Keliat, Akemal, Daulima, N. H. C., dan Nurhaeni, H. 2011. Keperawatan Kesehatan Komunitas Jiwa: CMHN Basic couse, EGC, Jakarta.

Keliat, B. A \& Subu, A. 2006. Modul IC CMHN: Manajemen Kasus Gangguan Jiwa dalam Keperawatan Kesehatan Jiwa Komunitas. Fakultas Ilmu Keperawatan Universitas Indonesia dan World Health Organization Indonesia, Jakarta.

Keliat, Budi, Anna. 2010. Model Praktik Keperawatan Profesional Jiwa. Edisi I.

Keliat, Riasmini, M., \& Daulima, N.H.C 2010. Efektivitas penerapan model community mental health nursing terhadap kemampuan hidup klien dengan gangguan jiwa dan keluarga di wilayah DKI Jakarta, Riset DRPM UI.

Maryam, R.S., Ekasari, M., Fatma., Rosidawati., Jubaedi, A., dan Batubara, Irwan. 2008. Mengenal Usia Lanjut dan Perawatannya. Salemba Medika, Jakarta. 
Mendoza-Núñez VM, Vivaldo-Martínez M, Martínez-Maldonado ML. Modelo comunitario de envejecimiento saludable enmarcado en la resiliencia y la generatividad. Rev Med Inst Mex Seguro Soc [Internet]. 2018 [cited 2018 Dec 17];56(Supl 1):S110-9. Available from: https://www.medigraphic.com/cgibin/new/resumen.cgi?IDARTICULO=80636 [ Links ]

Mubarak, W Iqbal. 2009. Ilmu Keperawatan Komunitas: Konsep Dan Aplikasi. Salemba Medika, Jakarta.

Notoadmodjo, S. 2007. Promosi Kesehatan dan Ilmu Perilaku : Rineka Cipta, Jakarta.

Nugroho. 2008. Gerontik dan Geriatrik. Karakteristik Lansia.

Padila. 2013. Buku Ajar Keperawatan Gerontik. Nuha, Yogyakarta.

Pambudi, WE., Dewi EI., Sulistyorini, Lantin. 2017. Pengaruh Terapi Aktivitas Kelompok Sosialisasi (TAKS) terhadap Kemampuan Interaksi Sosial pada Lansia dengan Kesepian di PSLU Jember. eJPK, Jember.

Potter, P.A. dan Perry, A.G. 2009. Fundamental of nursing: concept, process, and practice. Mosby Years Book Inc, Philadelphia.

Pusat Data dan Informasi Kementerian Kesehatan RI. 2013. Gambaran kesehatan lanjut usia di indonesia. Kementerian Kesehatan RI, Jakarta.

Putri, H.E. 2013. Gambaran tingkat aktivitas fisik lansia di kelurahan mekarwangi kecamatan tanah sareal kota bogor (Skripsi, Universitas Indonesia). Universitas Indonesia, Jakarta.

Rahmy AH, Prativa N, Andrianus R, Shalma M. 2020. Edukasi pedoman gizi seimbang dan isi piringku pada anak Sekolah Dasar Negeri 06 Batang anak Kabupaten padang Pariaman. Buletin Ilmiah Nagari Membangun. Vol 3 No 2: Juni 2020 http://buletinnagari.lppm.unand.ac.id/index.php/bln/article/view/208 DOI: https://doi.org/10.25077/bina.v3i2.208

Reno R,B. 2010. Hubungan Status Interaksi Sosial dengan Kualitas Hidup Lansia di Panti Wreda Dharma Bhakti Surakarta. Diakses tanggal 01 september 2019

Sarfika R, Hartati B, Putri dewi E. 2019 . Implementasi pendidikan kesehatan dengan metode brainstorming terhadap pengetahuan remaja tentang tumbuh kembang di pauh kota padang. Jurnal Hilirisasi IPTEKS, Vol 2 No 1 (2019): Maret, 2019.

http://hilirisasi.lppm.unand.ac.id/index.php/hilirisasi/article/view/226.DOI: htt ps://doi.org/10.25077/jhi.v2i1.226 
Sarfika R, Fernandes F. Mailia G. 2019. Pemberian pendidikan kesehatan untuk meningkatkan pengetahuan keluarga dalam merawat lansia demensia di Puskesmas Pauh, Kota Padang. Warta Pengabdian Andalas. file://C:/Users/HP/Downloads/355-Article\%20Text-608-1-10-20200628.pdf

Siswati S, Indra S, Ramadhani S. DKK. 2020. Pencegahan dan pengobatan teratur hipertensi melalui pembentukan Tim Gerak Nagari Sadar Hipertensi di wilayah kerja puskesmas Paninjauan Kabupaten solok. Buletin Ilmiah Nagari $\begin{array}{llllll}\text { Membangun. } & \text { Vol } & 3 & \text { No } & 20\end{array}$ http://buletinnagari.lppm.unand.ac.id/index.php/bln/article/view/204 DOI: https://doi.org/10.25077/bina.v3i2.204

Riyanto. 2015. Perbedaan Karakteristik Lansia Yang Tinggal Di Keluarga Dengan Yang Tinggal Di Panti Jakarta Barat. Skripsi. Universitas Atmajaya, Jakarta.

Rusilanti. 2006. Aspek Psikososial, Aktivitas Fisik, dan Konsumsi Makanan Lansia di Masyarakat. Skripsi. Institut Ilmu Kesehatan Bhakti Wiyata, Kediri.

Stanley M, Patricia GB. 2012. Buku Ajar Keperawatan Gerontik. Edisi 2. EGC, Jakarta.

Tamher, S. dan Noorkasiani. 2009. Kesehatan Usia Lanjut dengan Pendekatan Asuhan Keperawatan. Salemba Medika, Jakarta.

Varcarolis, E. M,. Dan Halter, M.J., 2010. Foundations Of Psychiatric Mental Health Nursing Clinical Approach. Sixth Edition. St Louse, New York

Videbeck, S. L. 2007. Psychiatric Mental Health Nursing. (4rd Ed). Lippincott Williams \& Wilkins, Philadhelpia.

Walgito, Bimo. 2010. Pengantar Psikologi Umum. Penerbit Andi, Yogyakarta.

Walijudi, Nugroho. 2008. Keperawatan Gerontik. EGC, Jakarta.

Widiasari, Yuki., Nuryoto, Sartini. 2010. Dinamika Psikologis Pencapaian Succesfull Aging Pada Lansia Yang Mengikuti Program Yanda Lansia. Pyscho Idea.Yogyakarta.

Taylor, J. 2013. Australian aged care-recipients right to spiritual care. Spiritual Health Victoria, Victoria.

Yulizawati, Bustami, Insani A, Fitrayeni. 2019. Partnerships dan Pemberdayaan masyarakat dalam pengembangan posdaya usia reproduksi dan lansia di Nagari Sumaniak. Warta Pengabdian Andalas. Vol 26 No 4.b (2019): Published in Desember 2019 http://wartaandalas.lppm.unand.ac.id/index.php/jwa/article/view/354. 